\title{
Application of Modified Sorption Material for Efficient Wastewater Treatment of Galvanic Production ${ }^{1}$
}

\author{
Olga G. Dubrovskay a, Vladimir A. Kulagin*a, \\ Tatiana A. Kurilina a and Feng-Chen $\mathbf{L i}^{\mathrm{b}}$ \\ ${ }^{a}$ Siberian Federal University \\ 79 Svobodny, Krasnoyarsk, 660041, Russia \\ ${ }^{b}$ School of Energy Science and Engineering \\ Harbin Institute of Technology \\ Harbin, 150001, China
}

Received 07.12.2016, received in revised form 11.03.2017, accepted 24.05.2017

The galvanic production is one of the source of environmental contamination by harmful substances and especially heavy metals. The questions of water pollution prevention by wastewater containing heavy metal ions, are closely linked to the development of event to reduce fresh water consumption for technological needs of production and to reduce the amount of wastewater. One solution to this problem is the creation of low-waste and waste-free environmentally safe production processes of sewage treatment with the use of treated wastewater in the working cycle, which leads to a reduction of negative impacts on the environment.

Keywords: sorption detoxification, heavy metal ions, modified sorbent, dolomite rocks.

Citation: Dubrovskay O.G., Kulagin V.A., Kurilina T.A., Li Feng-Chen. Application of modified sorption material for efficient wastewater treatment of galvanic production, J. Sib. Fed. Univ. Eng. technol., 2017, 10(5), 621-630. DOI: 10.17516/1999-494X2017-10-5-621-630.

(c) Siberian Federal University. All rights reserved

* Corresponding author E-mail address: v.a.kulagin@mail.ru 


\title{
Применение модифицированного сорбционного материала
}

\section{для эффективной очистки сточных вод}

\section{гальванического производства}

\author{
О.Г. Дубровская \\ Т.А. Курилина ${ }^{\mathbf{a}}$, Ф.-Ч. Ли \\ ${ }^{a}$ Сибирский федеральный университет \\ Россия, 660041, Красноярск, пр. Свободный, 79 \\ ${ }^{6}$ Школа энергетических наук и техники \\ Харбинский технологический институт \\ Китай, 150001, Харбин
}

Одним из источников загрязнения окружающей среды вредными веществами, в первую очередь тяжелыми металлами, являются гальванические производства. Вопросы предотвращения загрязнения водоемов сточными водами, содержащими ионы тяжелых металлов, тесно связаны с разработками мероприятий по сокращению потребления свежей воды на технологические нужды производства и уменьшению количества сбрасываемых стоков. Один из путей решения данной проблемы - создание малоотходных и безотходных экологически безопасных технологических процессов очистки сточных вод с использованием очищенных стоков в оборотном иикле, что приводит к снижению негативного воздействия на окружаюшую природную среду.

Ключевые слова: сорбиионное обезвреживание, ионы тяжельх металлов, модифицированный сорбент, доломитовые породы.

\section{The current state of the problem}

A sorption extraction of metals is one of the most effective methods of using electroplating wastewater treatment; the efficacy of sorption purification is $80-95 \%$ depending on the used sorbent. Sorption methods of wastewater treatment using the natural sorbents are acquainted for a long time, however, there is a large class of natural sorbents - minerals which due to the lack of knowledge is not widely used [16]. In the meantime, high sorptive properties, cheapness, abundance in nature make them cost-effective raw materials in technologies of treating industrial wastewater. The use of natural materials in wastewater treatment is acceptable from an environmental and economic point of view, but often such of materials do not have the desired sorptive properties, and they must be thermally modified. As a result of the modification, we obtain the sorbents which are different from the original mineral of natural surface which combine the useful properties of original material and the synthetic sorbents [7]. Therefore, the search of efficient and cost-effective natural sorbents for an intensification of wastewater treatment is an urgent problem $[8,9]$.

\section{Research technique}

We studied the sorptive method of heavy metal removal, as an example $\mathrm{Cu}$ (II); $\mathrm{Ni}$ (II) and $\mathrm{Zn}$ (II) from the aqueous solutions of a modified sorbent, based on the dolomite raw. This sorbent, Akdolit Kesselburger Pelm Gran CM3 (Akdolit-Gran) is produced in Germany and widely used in the West, and the European part of Russia. 
The sorbent material passes the thermal modification by heat treatment of a mineral. A calcination promotes loosening the rocks to form a structure with greater porosity and specific surface [10, 11]. The approximate chemical composition of Akdolit-Gran are calcium carbonate, $\mathrm{CaCO}_{3}-68,9 \%$; calcium oxide $\mathrm{CaO}-1,4 \%$; magnesium oxide $\mathrm{MgO}-25,4 \%$; magnesium carbonate $\mathrm{MgCO}_{3}-0,6 \%$; iron oxide $\mathrm{Fe}_{2} \mathrm{O}_{3}-0,6 \%$; alumina $\mathrm{Al}_{2} \mathrm{O}_{3}-2,7 \%$; silicon oxide $\mathrm{SiO}_{2}-0,3 \%$; water $\mathrm{H}_{2} \mathrm{O}-2,7 \%$. The presented values are average for several years of regular testing.

\section{Research results}

The aim of research was to study the physicochemical and sorptive properties of Akdolit-Gran sorbent.

For carrying out the sorption process in the laboratory environment was used a method of alternating batches of sorbent and constant volume of the initial concentration of the solution: $\mathrm{Cu}$ (II) $=60 \mathrm{mg} / \mathrm{dm}^{3}$; $\mathrm{Ni}(\mathrm{II})=15 \mathrm{mg} / \mathrm{dm}^{3} ; \mathrm{Zn}(\mathrm{II})=20 \mathrm{mg} / \mathrm{dm}^{3}$. These concentrations are most common in wastewater of the electroplating. The residual concentration was determined by an atomic emission spectrometer with inductively coupled plasma, ICAP-6500. Mineralogical sorbent composition was determined based on X-ray diffraction analysis performed on DRON-3, in a $\mathrm{Cu}-\mathrm{Ka}$ radiation, Fig. 1.

Analysis of diffraction patterns shows that the main phase in the sorbent is calcite $\mathrm{CaCo}_{3}(d=0.38$; $0.30 ; 0.23 ; 0.19 ; 0.18 \AA)$, in addition, there is a considerable amount of magnesium oxide $\operatorname{MgO}(d=0.21$; $0.15 \AA)$. Diffraction peaks with the low intensity correspond to magnesium hydroxide $\mathrm{Mg}(\mathrm{OH})_{2}(d=$ $0.21 ; 0.15 \AA)$ and calcium hydroxide $\mathrm{Ca}(\mathrm{OH})_{2}(d=0.49 ; 0.26 \AA)$, formed by hydrolysis of magnesium and calcium oxides contained in the sorbent.

The rest of the substances listed in the technical documentation for the sorbent $\left(\mathrm{MgCO}_{3}, \mathrm{Fe}_{2} \mathrm{O}_{3}\right.$, $\mathrm{Al}_{2} \mathrm{O}_{3}$, and $\mathrm{SiO}_{3}$ ) have been identified because of their low concentration. The thermal analysis was conducted for a more detailed study of the sorbent sample with the help of STA 449 F1 instrument (simultaneous thermal analyzer), NETZSCH company (Germany) in an inert argon gas environment.

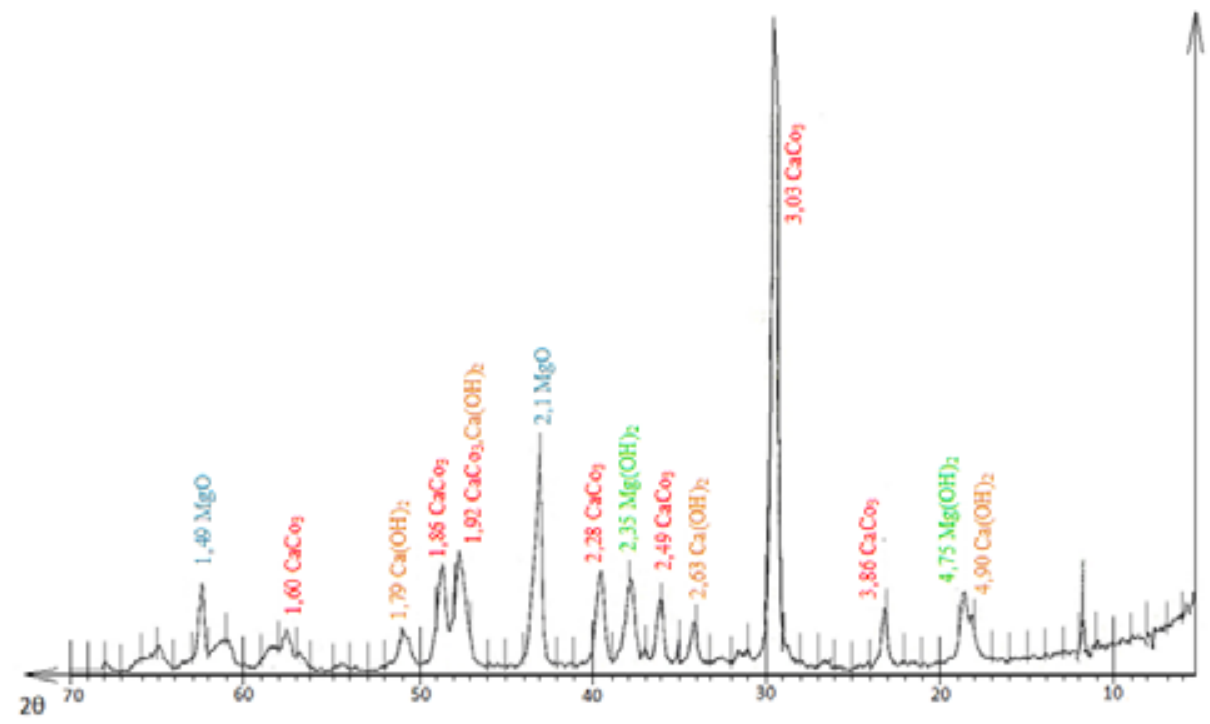

Fig. 1. The diffraction pattern of Akdolit-Gran sorbent 


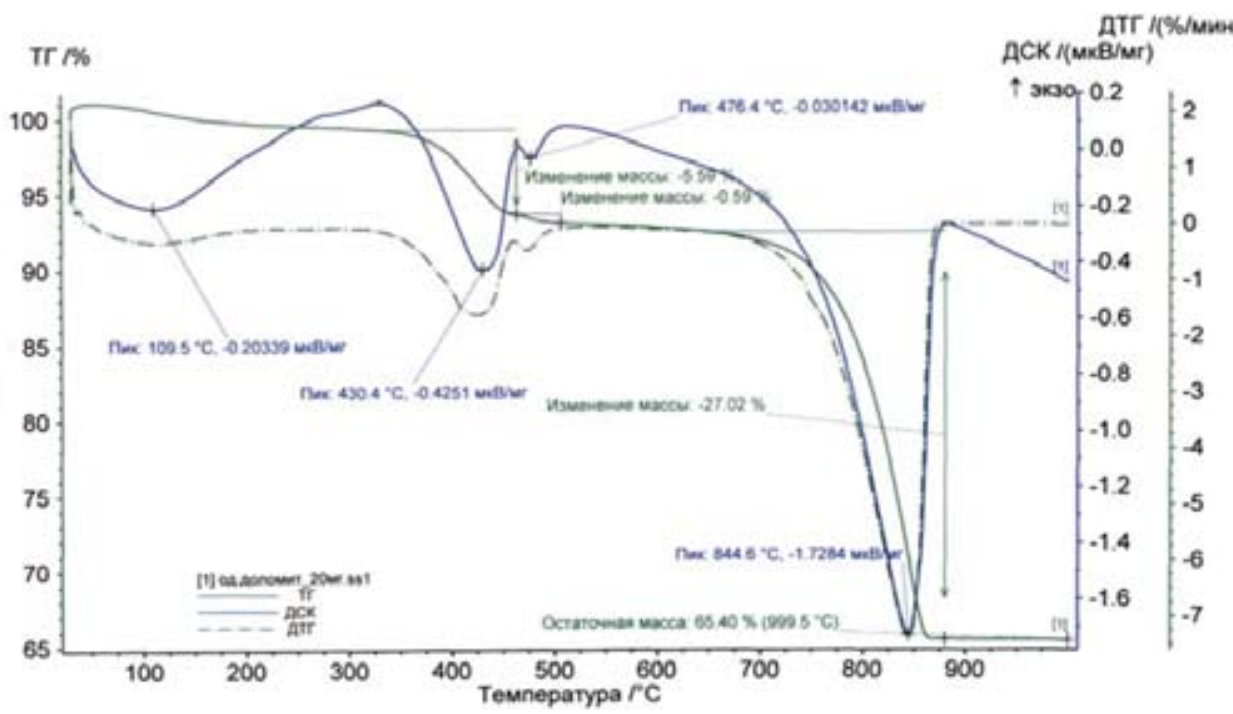

Fig. 2. The thermogram of sorbent Akdolit-Gran: DTC - differential thermogravimetric curve (showing a mass rate of change, this is the first derivative of the TG), TG - thermogravimetric curve, which shows the change-of mass during heating (mass increases or decreases), DSC - differential scanning curve (DSC and DTA show taking place at the on-heating the endo-and exothermic peaks, DTA - analysis from a single point, DSC - analysis with all on-surface)

A thermogram of sorbent sample Akdolit-Gran is shown in Fig. 2. A qualitative identification of the sample was produced according to the number, shape and position of various exo and endo-thermal peaks which are relative to the temperature scale.

Data of the sample thermal analysis show that the DSC curve are observed 4 endoeffect. Slight endoeffect at $109{ }^{\circ} \mathrm{C}$ relates to the removal of adsorbed water, endoeffect at $430{ }^{\circ} \mathrm{C}$ is caused by dehydration of $\mathrm{Mg}(\mathrm{OH})_{2}$ :

$$
\mathrm{Mg}(\mathrm{OH})_{2} \rightarrow \mathrm{MgO}+\mathrm{H}_{2} \mathrm{O}
$$

wherein the sample weight decreases, as the TG curve shows $\sim 5.59 \%$ at these temperatures, the compound $\mathrm{Mg}(\mathrm{OH})_{2}$ in a sample of $\sim 18 \%$ then is followed by endoeffect at $476{ }^{\circ} \mathrm{C}$, which is caused by dehydration of $\mathrm{Ca}(\mathrm{OH})_{2}$ :

$$
\mathrm{Ca}(\mathrm{OH})_{2} \rightarrow \mathrm{CaO}+\mathrm{H}_{2} \mathrm{O}
$$

the weight decreases by $0.59 \%$, there is a large endoeffect at $t=8440 \mathrm{~S}$ relating to the decarbonisation of calcite, ie the decomposition of calcite $\mathrm{CaCO}_{3}$ and $\mathrm{CO}_{2}$ formation:

$$
\mathrm{CaCO}_{3} \rightarrow \mathrm{CaO}+\mathrm{CO}_{2} \uparrow
$$

the sample weight is reduced approximately $27 \%, \mathrm{CaCO}_{3}$ content of the sample according to the thermogram $61.4 \%$.

According to the differential thermal and X-ray Akdolit-Gran analysis of sorbent, we can conclude in the process of heat treatment, the chemical transformation also occurs as a result calcium carbonate and magnesium oxide are formed. 
The standard techniques of sorbent were determined according to the standard procedures (Table 1). The dose values of proposed sorption material, which were found by experiment, are presented in Table 2.

The experiment (Table 2) showed that the cleaning effect using the sorbent Akdolit - Gran drastically reduced in an acidic medium. The reason of that could be a change of colloid-chemical properties of the sorbent, which the isoelectric point corresponds to approximately $\mathrm{pH}=5.4$, therefore if the $\mathrm{pH}$ values are below this value, the grain of sorbent loses the bimolecular gravitation of binary layer, which causes electrostatic repulsion of metal ions from the sorbent surface by contrast the typical gravitation of the alkaline medium. Furthermore, in the alkaline environment the metal ions are delivered to the reaction centers in the larger mass of sorbent metals.

The amount of copper ions in the sorbent phase (adsorption value) was calculated from A known equation [12].

Table 1. Specifications of the sorbent

\begin{tabular}{|l|c|}
\hline Total void content, $V_{\Sigma}\left(\mathrm{cm}^{3} / \mathrm{g}\right)$ & 0.103 \\
\hline Bulkdensity, $\rho_{\mathrm{H}}\left(\mathrm{g} / \mathrm{cm}^{3}\right)$ & 1.15 \\
\hline Real density $\rho\left(\mathrm{g} / \mathrm{cm}^{3}\right)$ & 2.37 \\
\hline Average density $\rho_{0}\left(\mathrm{~g} / \mathrm{cm}^{3}\right)$ & 2.26 \\
\hline Porosity $\Pi(\%)$ & 4.64 \\
\hline Water absorption $W(\%)$ & 10.3 \\
\hline
\end{tabular}

Table 2. Results of experiment

\begin{tabular}{|c|c|c|c|c|c|}
\hline № & $\begin{array}{c}\text { Reagent dose } \\
\mathrm{mg} / \mathrm{dm}^{3}\end{array}$ & $\begin{array}{c}\text { Values } \\
\mathrm{pH}\end{array}$ & $\begin{array}{c}\text { Residual concentration } \\
\mathrm{Cu}^{2+}, \mathrm{mg} / \mathrm{dm}^{3}\end{array}$ & $\begin{array}{c}\text { Residual concentration } \\
\mathrm{Ni}^{2+}, \mathrm{mg} / \mathrm{dm}^{3}\end{array}$ & $\begin{array}{c}\text { Residual concentration } \\
\mathrm{Zn}^{2+}, \mathrm{mg}^{2} \mathrm{dm}^{3}\end{array}$ \\
\hline 1 & 1.0 & 3.0 & 9.736 & 6.128 & 4.902 \\
\hline 2 & 1.0 & 7.0 & 0.123 & 0.183 & 0.0152 \\
\hline 3 & 1.0 & 9.0 & 1.131 & 0.199 & 0.0098 \\
\hline 4 & 1.0 & 11.0 & 1.268 & 6.103 & 3.663 \\
\hline 5 & 1.2 & 3.0 & 8.131 & 0.923 & 1.306 \\
\hline 6 & 1.2 & 7.0 & 0.305 & 0.163 & 0.0081 \\
\hline 7 & 1.2 & 9.0 & 0.192 & 0.198 & 3.569 \\
\hline 8 & 1.2 & 11.0 & 0.193 & 5.932 & 1.0061 \\
\hline 9 & 1.6 & 3.0 & 7.961 & 0.138 & 0.0062 \\
\hline 10 & 1.6 & 7.0 & 0.129 & 0.162 & 0.0161 \\
\hline 11 & 1.6 & 9.0 & 0.109 & 0.204 & 4.998 \\
\hline 12 & 1.6 & 11.0 & 0.203 & 5.862 & 1.0092 \\
\hline 13 & 2.0 & 3.0 & 7.805 & 0.132 & 0.0103 \\
\hline 14 & 2.0 & 7.0 & 0.905 & 0.193 & 0.0198 \\
\hline 15 & 2.0 & 9.0 & 0.129 & 0.235 & \\
\hline 16 & 2.0 & 11.0 & 0.151 & & \\
\hline
\end{tabular}


The absorbtion and concentration of substances from the solution at the surface and in the pores of the sorbent occur at the sorption. A metal distribution coefficient between the solution and carbonate $\mathrm{K}_{d}$ and also the degree of metal recovery from solution were determined. The calculation results are shown in Tables 3, 4.

Sorption ability of Akdolit - Gran differs in relation to the studied materials. The evaluation of the sorbent effectiveness for the metals extraction from aqueous solutions with the help of specific may lead to erroneous conclusions. Thus, evaluation of the effectiveness of heavy metals immobilization with the help of adsorptive capacity values gives the following series of sorption: $\mathrm{Cu}^{2+}>\mathrm{Zn}^{2+}>\mathrm{Ni}^{2+}$, but with the help of a metal distribution coefficient and the degree of metals recovery, we can see the following sequence: $\mathrm{Zn}^{2+}>\mathrm{Cu}^{2+}>\mathrm{Ni}^{2+}$. It is connected with the parameter of adsorptive capacity which depends on mass of the taken sample.

Ionic potential, i.e. the surface charge of the ion can be used to assess the degree of "surface dissociation". The ionic potential is determined by the formula

$$
\mathrm{IP}=\frac{n \cdot \mathrm{e}}{r},
$$

where $n$ - number of electrons; $\mathrm{e}$ - the electron charge.

For $\mathrm{Cu}^{2+}, \mathrm{Zn}^{2+}$ и $\mathrm{Ni}^{2+}$ the number of electrons are 2, and the electron charge is 1.602. There is a relationship the greater ion radius, the lower ionization potential. For $\mathrm{Cu}^{2+}$ the atoms radius is $1.278 \AA$; for $\mathrm{Zn}^{2+}$ the atoms radius is $1.333 \AA^{\circ}$ and $\mathrm{Ni}^{2+}$ the atom radius is $1.246 \AA$, on that basis, the investigated

Table 3. The sorption capacity of absorption Akdolit - Gran (mg/g)

\begin{tabular}{|c|c|c|c|c|}
\hline Number & $\begin{array}{c}\text { Dose } \\
\text { Akdolit }-\mathrm{Gran}, \mathrm{g} / \mathrm{dm}^{3}\end{array}$ & $\mathrm{Cu}^{2+}$ & $\mathrm{Ni}^{2+}$ & $\mathrm{Zn}^{2+}$ \\
\hline 1 & 1.0 & 57.74 & 13.01 & 19.87 \\
\hline 2 & 1.2 & 48.16 & 11.71 & 16.37 \\
\hline 3 & 1.4 & 41.28 & 10.27 & 14.14 \\
\hline 4 & 1.6 & 36.76 & 8.63 & 12.35 \\
\hline 5 & 1.8 & 32.26 & 7.26 & 10.54 \\
\hline 6 & 2.0 & 28.15 & 6.37 & 9.19 \\
\hline
\end{tabular}

Table 4. The metal distribution coefficient between the solution and sorbent $(\mathrm{g} / \mathrm{dm} 3)$

\begin{tabular}{|c|c|c|c|c|}
\hline Number & $\begin{array}{c}\text { Dose } \\
\text { Akdolit }-\mathrm{Gran}, \mathrm{g} / \mathrm{dm}^{3}\end{array}$ & $\mathrm{Cu}^{2+}$ & $\mathrm{Ni}^{2+}$ & $\mathrm{Zn}^{2+}$ \\
\hline 1 & 1.0 & 25.59 & 6.55 & 155.23 \\
\hline 2 & 1.2 & 21.81 & 12.48 & 45.98 \\
\hline 3 & 1.4 & 18.68 & 16.48 & 67.98 \\
\hline 4 & 1.6 & 31.20 & 7.29 & 52.55 \\
\hline 5 & 1.8 & 16.69 & 3.77 & 10.28 \\
\hline 6 & 2.0 & 7.61 & 2.83 & 5.64 \\
\hline
\end{tabular}


metals are arranged in series: $\mathrm{Zn}^{2+}>\mathrm{Cu}^{2+}>\mathrm{Ni}^{2+}$, which corresponds to the experimentally obtained data.

Table 5 is shown the kinetic dependence of sorption process of copper ion (II), nickel (II) and zinc (II).

It also gives the following sequence of metals distribution under extraction rate

$$
\mathrm{Zn}^{2+}>\mathrm{Cu}^{2+}>\mathrm{Ni}^{2+}
$$

It is known that the sorption process is exothermic, as the temperature increases, the sorbent capacity reduces in relation to the metals $[14,15]$, which is confirmed by the results of Table 6 .

The phenomena of the physical and chemical sorption are clearly distinguished in rare cases. Usually, the intermediate options are carried out, when the mass of the adsorbed substance links relatively weakly, and only a small part is firmly [16-18]. The chemical adsorption occurs, as the temperature increases, which begins to overlap the downfall of physical sorption at definite temperature. (Table 7).

These experimental studies were used to develop the project on reconstruction of treatment facilities with the proposed sorption material.

\section{Conclusion}

The study's results of sorption properties of natural modified mineral Akdolit - Gran show that it is highly effective sorbent, being relatively cheap natural mineral, which can provide the treatment

Table 5. The degree of metal recovery from solution ( \%)

\begin{tabular}{|c|c|c|c|c|}
\hline Number & $\begin{array}{c}\text { Dose } \\
\text { Akdolit }-\mathrm{Gran}, \mathrm{g} / \mathrm{dm}^{3}\end{array}$ & $\mathrm{Cu}^{2+}$ & $\mathrm{Ni}^{2+}$ & $\mathrm{Zn}^{2+}$ \\
\hline 1 & 1.0 & 96.24 & 86.76 & 99.36 \\
\hline 2 & 1.2 & 96.32 & 93.75 & 98.22 \\
\hline 3 & 1.4 & 96.32 & 95.85 & 98.96 \\
\hline 4 & 1.6 & 98.03 & 92.11 & 98.92 \\
\hline 5 & 1.8 & 96.78 & 87.16 & 94.87 \\
\hline 6 & 2.0 & 93.83 & 84.94 & 91.86 \\
\hline
\end{tabular}

Table 5. The results of calculation of the rate constant, depending on the reagent dose

\begin{tabular}{|c|c|c|c|}
\hline \multirow{2}{*}{$\begin{array}{c}\text { Doses } \\
\mathrm{mg} / \mathrm{dm}^{3}\end{array}$} & \multicolumn{3}{|c|}{$K, \mathrm{se \kappa}^{-1}$} \\
\cline { 2 - 4 } & $\mathrm{Cu}^{2+}$ & $\mathrm{Ni}^{2+}$ & $\mathrm{Zn}^{2+}$ \\
\hline 1.0 & 3.28 & 2.02 & 5.05 \\
\hline 1.2 & 3.3 & 2.77 & 4.02 \\
\hline 1.4 & 3.3 & 3.18 & 4.56 \\
\hline 1.6 & 3.9 & 2.54 & 4.44 \\
\hline 1.8 & 3.4 & 2.05 & 2.97 \\
\hline 2.0 & 2.78 & 1.89 & 2.51 \\
\hline
\end{tabular}


Table 6. The dependence of the adsorptive capacity of the solution temperature, $\mathrm{mg} / \mathrm{g}$

\begin{tabular}{|c|c|c|c|c|}
\hline Number & Temperature ${ }^{\circ} \mathrm{C}$ & $\mathrm{Cu}(\mathrm{II})$ & $\mathrm{Ni}(\mathrm{II})$ & $\mathrm{Zn}(\mathrm{II})$ \\
\hline 1 & 11.5 & 41.78 & 10.22 & 14.06 \\
\hline 2 & 17.0 & 42.75 & 10.59 & 14.28 \\
\hline 3 & 25.0 & 42.76 & 10.63 & 14.26 \\
\hline 4 & 33.0 & 42.76 & 10.67 & 14.27 \\
\hline 5 & 38.5 & 42.77 & 10.70 & 14.22 \\
\hline 6 & 60.0 & 42.76 & 10.62 & 14.20 \\
\hline 7 & 70.5 & 42.71 & 10.61 & 14.14 \\
\hline 8 & 80.0 & 42.71 & 10.57 & \\
\hline
\end{tabular}

Table 7. The calculation results of the residual concentration depending on the environmental temperature

\begin{tabular}{|c|c|c|c|}
\hline \multirow{2}{*}{ Temperature ${ }^{\circ} \mathrm{C}$} & \multicolumn{3}{|c|}{$C_{\text {ex. }}$} \\
\cline { 2 - 4 } & $\mathrm{Cu}(\mathrm{II})$ & $\mathrm{Ni}(\mathrm{II})$ & $\mathrm{Zn}(\mathrm{II})$ \\
\hline 11.5 & 2.201 & 0.689 & 0.308 \\
\hline 17.0 & 0.151 & 0.161 & 0.005 \\
\hline 25.0 & 0.128 & 0.112 & 0.031 \\
\hline 33.0 & 0.131 & 0.056 & 0.0053 \\
\hline 38.5 & 0.121 & 0.013 & 0.0101 \\
\hline 60.0 & 0.136 & 0.128 & 0.0805 \\
\hline 70.5 & 0.207 & 0.146 & 0.108 \\
\hline 80.0 & 0.210 & 0.202 & 0.196 \\
\hline
\end{tabular}

from the complex contamination of heavy metal ions to the required parameters in the purification of circulating water and refuse pulp.

We can draw the following conclusions from the results:

1. It is appropriate to use the sorbent for wastewater electroplating purification by way of a potential sorbention exchanger because the ion exchanger is calcium and magnesium ions.

2. The sorption of cations occurs as the mechanism of ion exchange (the exchange with the cations which are situated in the interstices spaces) and by the formation of complex connections.

3. The optimum dose of sorption material Akdolit - Gran is approximately $1,4-1,6 \mathrm{gr} / \mathrm{dm}^{3}$ for solutions with initial concentration: $\mathrm{Cu}$ (II) $=60 \mathrm{mg} / \mathrm{dm}^{3} ; \mathrm{Ni}(\mathrm{II})=15 \mathrm{mg} / \mathrm{dm}^{3}$; $\mathrm{Zn}(\mathrm{II})=20 \mathrm{mg} / \mathrm{dm}^{3}$, temperature conditions are in the range $33,0-38,0{ }^{\circ} \mathrm{C}$.

4. A treatment effect of using sorbent Akdolit - Gran is drastically reduced in an acidic media.

The reported study was funded by Russian Foundation for Basic Research, Government of Krasnoyarsk Territory, Krasnoyarsk Region Science and Technology Support Fund to the research projects №̄ № 17-48-240386 p_a and 16-41-242156 p_oфu_M.

1 These authors contributed equally to this work. 


\section{References}

[1] Бек Р.Ю. Воздействие гальванотехнических производств на окружаюшую среду и способы снижения наносимого ущерба, Аналитический обзор АН СССР. Сиб. отд-ние. Ин-т химии твердого тела и переработки минерального сырья; Новосибирск: ГПНТБ, 1991. 96 с. [Beck R.Y. The impact of electroplating plants on the environment and ways to reduce the caused damage, Analytical review of the Academy of Sciences of the USSR. Sib. Dep-nt. Institute of Chemistry Solid State and mineral processing; Novosibirsk: GPNTB, 1991. 96 p. (in Russian)]

[2] Тарасевич Ю.И. Природные сорбенты в прочессах очистки воды. Киев: Наукова думка, 1981. 206 с. [Tarasevich Y.I. Natural sorbents in water purification processes. Kiev: Naukova Dumka, 1981. 206 p. (in Russian)]

[3] Алыков Н.М., Павлова А.В., Нгуэн К.Х. и др. Новый сорбент для очистки воды от ионов токсичных металлов, Естественные науки. Журнал фундаментальных и прикладных исследований, 2009, 4(29), 150-158. [Alykov N.M., Pavlova A.V., Nguyen K.H. etc. New sorbent for water purification from ions of toxic metals, Natural sciences. Journal of basic and applied research, 2009, 4(29), 150-158. (in Russian)]

[4] Джигола Л.А., Симакова Ю.М., Рублева А.В. и др. Изучение сорбции на опоках и диффузии в глинах ионов тяжелых металлов, Естественные науки. Журнал фундаментальных и прикладных исследований, 2009, 4(29), 175-180. [Dzhigola L.A., Simakova Y.M., Rubleva A.V. etc. Studying the sorption at flasks and diffusion in clays of heavy metal ions, Natural sciences. Journal of basic and applied research, 2009, 4(29). 175-180. (in Russian)]

[5] Рогалева Е.В., Воронцова Н.В., Пилипенко А.И., Ганяев В.П. Очистка природных вод от ионов тяжелых металлов методом сорбции и озонирования, Известия высших учебных заведений. Нефть и газ, 2008, 2, 102-104. [Rogaleva E.V., Vorontsova N.V., Pilipenko A.I., Ganyaev V.P. Water purification from heavy metal ions by adsorption and ozonation, Proceedings of the higher educational institutions. Oil and gas, 2008, 2, 102-104 (in Russian)]

[6] Хурамшина И.З., Никифоров А.Ф., Мигалатий Е.В., Баранов О.Ю. Взаимодействие меди (II) с природным минеральным сорбентом в процессах очистки водных растворов, Водоочистка. Водоподготовка. Водоснабжение, 2008, 2(74), 22-26. [Huramshina I.Z., Nikiforov A.F., Migalaty E.V. Baranov O.Y. Interaction of copper (II) with a natural mineral sorbent during purification of aqueous solutions, Water purification. Water treatment. Water supply, 2008, 2(74), 22-26 (in Russian)]

[7] Никифоров А.Ю. Использование природного минерала доломита и его термомодифицированных форм для очистки сточных вод от катионов тяжелых металлов, Изв. вузов. Химия и химическая технология, 1999, 4. [Nikiforov, A.Y. Using the natural mineral dolomite and its thermally-modified forms for waste water purification from heavy metal cations, Proceedings of the higher educational institutions. Chemistry and chemical technology, 1999, 4 (in Russian)]

[8] Nadeem R., Hanif M., Shaheen F. et al. Physical and chemical modification of distillery sludge for $\mathrm{Pb}(\mathrm{II})$ biosorption, J. Hazard. Matter, 2008, 150, 335-342.

[9] Padmavathy V. Biosorption of nickel (II) ions by baker's yeast: Kinetic, thermodynamic and desorption studies, Bioresource. Technol, 2008, 99, 3100-3109.

[10] Годымчук А.Ю., Решетова А.А. Исследование процессов извлечения тяжелых металлов на природных минералах, Вестник Отделения наук о Земле РАН [Электронный

$$
-629-
$$


научно-информационный журнал], 2003, 1(21), URL: http://www.scgis.ru/russian/cp1251/h_ dgggms/1-2003/informbul-1/hydroterm-17.pdf [Godymchuk A.Y., Reshetova A.A. Investigation of extraction processes of heavy metals at natural minerals Herald of the Earth Sciences Department RAS [Electronic Scientific Information Journal] 2003. 1.(21) URL: http://www.scgis.ru/russian/cp1251/h_ dgggms/1-2003/informbul-1/hydroterm-17.pdf (in Russian)]

[11] Ниязи Ф.Ф., Мальцева В.С., Сазонова А.В. Кинетические закономерности сорбции ионов железа (II, III) модифицированными карбонатными породами, Известия ЮЗГУ. Серия Физика и химия, 2012, 1, 40-47. [Niyazi F.F., Maltseva V.S., Sazonova A.V. Kinetics of sorption iron ions (II, III) modified by carbonate rocks, Proceedings YZGU. Series Physics and Chemistry, 2012, 1, 40-47. (in Russian)]

[12] Домрачева В.А. Извлечение металлов сточных вод и техногенных образований. Иркутск: Из-во ИрГТУ, 2006. 151 с. [Domracheva V.A. Extracting metals of wastewater and industrial structures. Irkutsk: Publishing office of Irkutsk State Technical University, 2006. 151 p. (in Russian)]

[13] Левченко С.И. Физическая и коллоидная химия. Конспект лекиий для студентов биофака ЮФУ http://www.physchem.chimfak.rsu.ru/. Ростов на Дону, 2004. 77 c. [Levchenko S.I. Physical and Colloid Chemistry. Lectures for students of biological faculty of JFU http://www. physchem.chimfak.rsu.ru/ Rostov-on-Don, 2004, 77 p. (in Russian)]

[14] Бикулова В.Ж., Латыпова Ф.М., Мухаметдинова Л.Х. Адсорбционная очистка промышленных сточных вод от ионов цинка, Вода, химия и экология. 2013, 3. [Bikulova V.Zh., Latypova F.M., Muhametdinova L.H. Adsorption treatment of industrial waste water from zinc ions, Water, chemistry and ecology, 2013, 3. (in Russian)]

[15] Оразова С.С., Белов В.М., Евстигнеев В.В. Эффективность использования природных сорбентов восточного Казахстана в очистке воды от ионов тяжелых металлов $\left(\mathrm{Cu}^{2+}\right)$, Известия Томского политехнического университета, 2007, № 2, 311. [Orazova S.S., Belov V.M., Evstigneev V.V. The effectiveness of the use of natural sorbents from eastern Kazakhstan in water purification from heavy metal ions ( $\mathrm{Cu} 2+)$, Proceedings of the Tomsk Polytechnic University, 2007, 2, 311. (in Russian)]

[16] Андрышев А.К., Колпаков В.П., Лопухов Ю.И., Даумова Г.К. Об эффективной технологии очистки хромсодержащих сточных вод с применением модифицированных сорбентов, Водоочистка. Водоподготовка. Водоснабжение, 2014, 9. [Andryshev A.K., Kolpakov V.P., Lopuhov Y.I., Daumova G.K. An effective cleaning technology of chromium-containing wastewater with modified sorbents, Water Treatment. Water production. Water supply, 2014, 9. (in Russian)]

[17] Щербаков А.В. Очистка стоков от солей тяжелых металлов, Энергосбережение $u$ водоподготовка, 2013, 3. [Shcherbakov A.V. Wastewater treatment of heavy metals salts, Energy saving and water treatment, 2013, 3. (in Russian)]

[18] Баталова Ш.Б. Физико-химические основы получения и применения катализаторов и адсорбентов из бентонитов, Алма-Ата: Наука, 1986, 168 c. [Batalova S.B. Physical and chemical bases of reception and application of catalysts and adsorbents from bentonite, Alma-Ata, Nauka, 1986, 168 p. (in Russian)] 